\title{
Metatranscriptomes of redox-different natural aquifer surrounding a uranium roll-front deposit
}

\author{
FADWA JROUNDI ${ }^{1}$, MICHAEL DESCOSTES ${ }^{2}$, CRISTINA \\ POVEDANO-PRIEGO ${ }^{1}$ AND MOHAMED L. MERROUN ${ }^{1}$ \\ ${ }^{1}$ Department of Microbiology, Faculty of Sciences, University of \\ Granada \\ ${ }^{2}$ Orano Mining
}

Presenting Author: fadwa@ugr.es

Recovery of naturally occurring uranium is performed by several approaches, among which U-ISR (Uranium In Situ Recovery) is the most effective for the economical extraction from low-grade roll-front deposits. Microorganisms may play an important role at all U-ISR stages, however, the effect of native bacteria subjected to such stress has been insufficiently investigated. The focus here was to determine the active diversity of bacteria residing in an aquifer surrounding uranium roll-front deposit. Pristine waters were collected at Zoovch Ovoo, Mongolia, from the mineralized orebody, the up-stream and down-stream compartments, before any U-ISR interventions.

An imposed chemical zonation for all sensitive redox elements was observed through the roll-front system. Metatranscriptomic results showed the presence in all compartments of interesting bacteria such as sulphate-reducing bacteria (e.g. Desulfovibrio, Nitrospira), iron-reducing bacteria (e.g. Gallionella, Sideroxydans), iron-oxidizing bacteria (e.g. Rhodobacter, Albidiferax, Ferribacterium), nitrate-reducing bacteria (e.g. Pseudomonas, Aquabacterium), probably involved in metal reduction, e.g. uranium, as well as acidophilic bacteria. Several genes encoding metabolic activities such as sulphate reduction, sulphur assimilation (SUF), cytochromes, and nitrate/nitrite reductase, indicating high diversity of different metabolisms were detected. According to their activities, the native bacteria may play an important role in the remediation of ISR cocontaminants such as $\mathrm{NO}_{3}, \mathrm{SO}_{4}$, $\mathrm{U}$, etc.

As a whole, the bacterial community in each compartment may define an ecologically functional ecosystem containing suitable microorganisms prone to promote remediation of the acidified aquifer. Finally, our results help understanding natural attenuation process, as remediation strategy, and predicting bacterial inputs in improving ISR efficiency, avoiding thus environmental risks. 